\title{
Preservation of Essential Odor-Guided Behaviors and Odor-Based Reversal Learning after Targeting Adult Brain Serotonin Synthesis
}

\author{
Kaitlin S. Carlson,, ${ }^{*}$ Meredith S. Whitney, ${ }^{*}$ Marie A. Gadziola, ${ }^{\circledR}$ Evan S. Deneris, ${ }^{\ddagger}$ and \\ (1)Daniel W. Wesson ${ }^{\ddagger}$
}

DOI:http://dx.doi.org/10.1523/ENEURO.0257-16.2016

Department of Neurosciences, Case Western Reserve University, Cleveland, OH, 44106

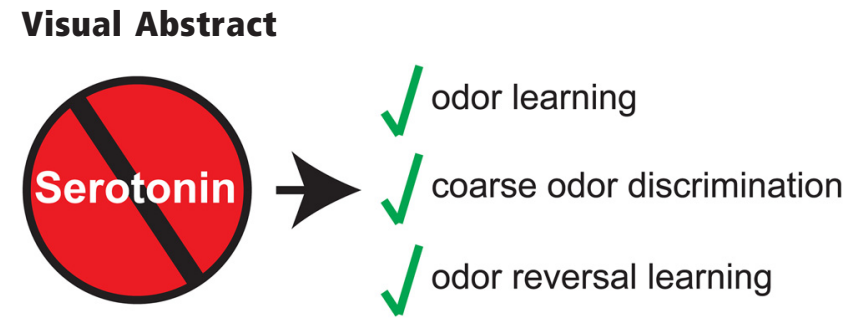

The neurotransmitter serotonin $(5-\mathrm{HT})$ is considered a powerful modulator of sensory system organization and function in a wide range of animals. The olfactory system is innervated by midbrain $5-\mathrm{HT}$ neurons into both its primary and secondary odor-processing stages. Facilitated by this circuitry, 5-HT and its receptors modulate olfactory system function, including odor information input to the olfactory

bulb. It is unknown, however, whether the olfactory system requires 5-HT for even its most basic behavioral functions. To address this question, we established a conditional genetic approach to specifically target adult brain tryptophan hydroxylase 2 (Tph2), encoding the rate-limiting enzyme in brain 5-HT synthesis, and nearly eliminate 5-HT from the mouse forebrain. Using this novel model, we investigated the behavior of 5-HT-depleted mice during performance in an olfactory go/no-go task. Surprisingly, the near elimination of 5-HT from the forebrain, including the olfactory bulbs, had no detectable effect on the ability of mice to perform the odor-based task. Tph2-targeted mice not only were able to learn the task, but also had levels of odor acuity similar to those of control mice when performing coarse odor discrimination. Both groups of mice spent similar amounts of time sampling odors during decision-making. Furthermore, odor reversal learning was identical between 5-HT-depleted and control mice. These results suggest that 5-HT neurotransmission is not necessary for the most essential aspects of olfaction, including odor learning, discrimination, and certain forms of cognitive flexibility.

Key words: 5-HT; odor discrimination; odor learning; operant behavior; psychophysics; reversal learning

\section{Significance Statement}

Modulation of sensory systems by neurotransmitters is considered critical for perception. The olfactory system is robustly innervated by serotonin $(5-\mathrm{HT})$ neurons into both its primary and secondary odor-processing stages. Facilitated by this circuitry, 5-HT and its receptors modulate olfactory system function, including odor information input to the olfactory bulb. Here we asked whether the olfactory system needs $5-\mathrm{HT}$ by using a conditional genetic approach to specifically target adult brain 5-HT synthesis and nearly eliminate 5-HT from the mouse forebrain. Our results suggest that 5-HT neurotransmission is not required for the most essential aspects of olfaction, including odor learning, odor discrimination, and odor-based cognitive flexibility. These findings raise questions about the importance and precise role of 5-HT modulation in olfactory system circuitry. 


\section{Introduction}

Our sensory systems must encode information under a wide range of dynamic contexts for survival. One way the brain handles this task is to modulate the activity within local sensory processing centers by means of extrinsic substances. In this manner, top-down centers that produce neuromodulators can differentially release these modulators in sensory centers depending on the needs of the animal. Major questions remain, however, regarding what neuromodulators are necessary for normal sensory system function (Katz, 1999; Hurley et al., 2004; Bouret and Sara, 2005; Linster and Fontanini, 2014).

The neurotransmitter serotonin $(5-\mathrm{HT})$ is considered a powerful modulator of sensory system organization and function in a wide range of animals (Hen, 1992; Jacobs and Azmitia, 1992; Cases et al., 1996). The mammalian olfactory system is innervated by $5-\mathrm{HT}$ neurons into both its primary and secondary odor processing stages (McLean and Shipley, 1987; Smith et al., 1993; Steinfeld et al., 2015; Suzuki et al., 2015). Midbrain $5-\mathrm{HT}$ neurons located in the dorsal raphe nucleus (DRN) and median raphe nucleus (MRN) innervate the olfactory bulb, where fibers are observed in several cell layers (McLean and Shipley, 1987; Steinfeld et al., 2015; Suzuki et al., 2015; Muzerelle et al., 2016), including surrounding the glomeruli, which represent the first synaptic processing stage of odor information.

Facilitated by this circuitry, 5-HT and its receptors modulate olfactory system function (McLean et al., 1993; Aungst and Shipley, 2005; Hardy et al., 2005; Petzold et al., 2009; Liu et al., 2011a; Schmidt and Strowbridge, 2014; Brill et al., 2016; Brunert et al., 2016; Kapoor et al., 2016; Linster and Cleland, 2016; Lottem et al., 2016). For instance, electrical stimulation of the raphe nuclei modulates the level of odor information input into the olfactory bulb (Petzold et al., 2009). Additionally, optogenetic stimulation of raphe nuclei 5-HT neurons alters the representation of odors in several major populations of olfactory bulb neurons, including the primary output neurons (Brunert et al., 2016). Importantly, most of the above

Author contributions: KSC, MSW, ESD, and DWW designed research; KSC and MSW performed research; KSC, MSW, MAG, ESD, and DWW analyzed data and wrote the paper.

Supported by the National Institute on Deafness and Other Communication Disorders, National Institutes of Health [100000055; R01DC014443 (D.W.W.); F31DC014615 (K.S.C)], the National Institute of Mental Health, National Institutes of Health [100000025; R01MH062723 (E.S.D.), P50MH096972 (E.S.D.); F30MH099704 (M.S.W.)], the Case Western Reserve University Medical Scientist Training Program (T32GM007250), and National Science Foundation grant IOS-1121471 (D.W.W.).

${ }^{*}$ K.S.C. and M.S.W. contributed equally to this work and are co-first authors.

${ }^{\ddagger}$ E.S.D. and D.W.W. contributed equally to this work and are co-senior authors.

Acknowledgments: We thank Maryanne Pendergast for assistance with imaging and Zhou-Feng Chen (Washington University) for the Tph ${ }^{f l / f l}$ mice.

Correspondence should be addressed to either of the following: Daniel W. Wesson. E-mail: dww53@case.edu; or Evan S. Deneris. E-mail: esd@case.edu, 2109 Adelbert Rd Dept of Neurosciences Cleveland, OH, 44106.

DOI:http://dx.doi.org/10.1523/ENEURO.0257-16.2016

Copyright (C) 2016 Carlson et al.

This is an open-access article distributed under the terms of the Creative Commons Attribution 4.0 International, which permits unrestricted use, distribution and reproduction in any medium provided that the original work is properly attributed. studies performed manipulations aimed at enhancing levels of synaptic $5-\mathrm{HT}$ in the olfactory system. It is unknown, however, whether the olfactory system requires $5-\mathrm{HT}$ for even its most basic behavioral functions.

In the present study, we investigated the behavior of mice with conditional depletions of adult brain 5-HT synthesis during their performance in an olfactory go/no-go task (Bodyak and Slotnick, 1999; Slotnick and Restrepo, 2001). To accomplish this, we used a recently established conditional approach (Whitney et al., 2016) to specifically target adult brain 5-HT synthesis, which nearly eliminates $5-\mathrm{HT}$ from the entire mouse forebrain. Conditional targeting of adult brain 5-HT synthesis, together with wellestablished operant methods to robustly assay olfactory psychophysics, allowed to us test whether the adult olfactory system requires $5-\mathrm{HT}$ for fundamental aspects of odor-guided operant behaviors, including odor learning and coarse odor discrimination. Our results suggest that adult brain 5-HT is not necessary for elementary function of the mammalian olfactory system.

\section{Materials and Methods}

\section{Group design}

Three different cohorts of Tph2 $2^{f \mid f l}$ male mice (Kim et al., 2014) were used throughout this study (Fig. 1). These cohorts provided opportunities to confirm the depletion of adult 5-HT using immunohistochemical, molecular, and chemical methods as well as to test the functional effects of $5-\mathrm{HT}$ depletion using behavioral methods.

\section{Surgical procedures and animal care}

All animal procedures were in accordance with the guidelines of the National Institutes of Health and were approved by the Institutional Animal Care and Use Committee at Case Western Reserve University. Young adult mice ( $\sim 8$ weeks of age) underwent a single survival intracranial surgical procedure to receive adeno-associated virus (AAV) as described in Whitney et al. (2016). After induction in isoflurane anesthetic $\left(3.0-3.5 \%\right.$ in $1 \mathrm{l} / \mathrm{min} \mathrm{O}_{2}$ ), the mice were mounted into a stereotaxic frame and the anesthetic state was maintained under isoflurane. Core body temperature was maintained at $38^{\circ} \mathrm{C}$ with a heating pad. Upon confirmation of anesthesia depth, the head was shaved and cleaned with betadine and $70 \% \mathrm{EtOH}$, and a single injection of marcaine (s.c.) was administered within the site of the future wound margin. A single midline incision was made from $\sim 3 \mathrm{~mm}$ posterior of the nose along the midline to $\sim 3 \mathrm{~mm}$ posterior of lambda. Two holes ( $\sim 1$ - $\mathrm{mm}$ diameter) were drilled $\pm 0.4 \mathrm{~mm}$ from the midline of the skull $(-4.15 \mathrm{~mm}$ from bregma). A $10-\mu \mathrm{l}$ Gastight 1701 Hamilton syringe (30-gauge needle with a $13^{\circ}$ bevel; Hamilton, Reno, NV) loaded with AAV (either AAV1.CMV.PI.Cre.rBG or AAV1.CMV.PI.EGFP.WPRE.bGH; Penn Vector Core, Philadelphia, PA) was lowered into the intended injection site $(-4.0 \mathrm{~mm}$ ventral), and $1 \mu \mathrm{l}$ of AAV was infused at a rate of $100 \mathrm{nl} / \mathrm{min}$. After the first injection, the syringe was slowly raised out of the brain and the process was repeated at the second site. After the second injection, the craniotomies and skull were closed. Rimadyl (carprofen, 5 mg/kg s.c.; Pfizer, Groton, CT) was adminis- 
A

Histology

Cohort 1

$n=4$ AAV-GFP, 2 AAV-Cre
B

\section{Behavior, HPLC, \& qPCR}

Cohort 2

$n=5$ AAV-GFP, 3 AAV-Cre

Cohort 3

$n=4$ AAV-GFP, 5 AAV-Cre $\checkmark A A V-G F P$ death

4AAV-Cre death

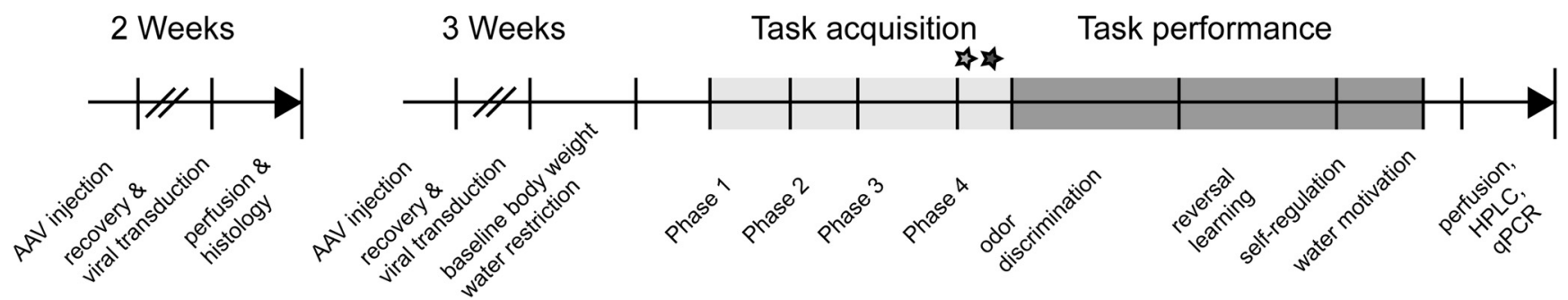

Figure 1. Experimental timeline for all mouse cohorts. Three separate cohorts of $T p h 2^{f l / f l}$ male mice were used. $\boldsymbol{A}$, Cohort 1 was used solely for immunohistochemistry. $\boldsymbol{B}$, Cohorts 2 and 3 were used for olfactory go/no-go behavioral experiments and, after behavioral data collection, perfused for subsequent qPCR and HPLC analyses of postmortem brain tissue (see Materials and Methods). Two mice from the behavioral group (cohorts 2 and 3) were euthanized or died during the late stages of task acquisition after displaying signs of illness (indicated by stars).

tered daily for $3 \mathrm{~d}$ after surgery. Food and water were available ad libitum except during behavioral recordings. All animals were returned to group housing the day of surgery on a 12:12-h (light:dark) schedule. Any mice exhibiting delayed recovery or signs of illness (lethargy, immobility, ungroomed fur) throughout any point of experimentation were immediately euthanized and not used for future data collection.

\section{Histology}

As illustrated in Figure 1, a cohort of mice (cohort 1) not used in the behavioral testing was treated with AAV as described above and prepared for immunohistochemical staining for 5-HT and Tph2. Two weeks postsurgery, the mice were anesthetized with Avertin ( $0.5 \mathrm{~g}$ tribromoethanol/39.5 $\mathrm{ml} \mathrm{H}_{2} \mathrm{O}, 0.02 \mathrm{ml} / \mathrm{g}$ ) and perfused with cold PBS for 2-5 $\mathrm{min}$, followed by cold $4 \%$ paraformaldehyde in PBS for $20 \mathrm{~min}$. The brains were removed and cryoprotected in 30\% sucrose:PBS overnight. Next, frozen coronal sections through the olfactory bulb and piriform cortex were obtained on a sliding microtome at $20-\mu \mathrm{m}$ thickness and placed in $0.3 \%$ sodium azide/Tris-buffered saline at $4^{\circ} \mathrm{C}$ until staining. The remaining midbrain and hindbrain tissue was left in $30 \%$ sucrose:formalin until sectioning, when $20-\mu \mathrm{m}$ frozen sections through all serotonergic nuclei were made on a sliding microtome. Similar sections from AAV-GFP- and AAV-Cre-injected mice were mounted on slides and vacuum-dried. They were then permeabilized in $0.3 \%$ Triton X-100:PBS (PBS-T) and blocked in $5 \%$ normal goat serum in PBS-T. Before blocking, antigen retrieval was performed only on slides containing sections through the serotonergic nuclei because of overfixation from formalin. Slides were placed in $10 \mathrm{~mm}$ sodium citrate, microwaved at low power for $10 \mathrm{~min}$, cooled to room temperature, and washed three times for $5 \mathrm{~min}$ in PBS. All slides were then incubated in primary antibody in blocking solution $\mathrm{O} / \mathrm{N}$ at $4^{\circ} \mathrm{C}$, washed six times for 5 min in PBS-T, incubated in secondary antibody, and washed six times for $5 \mathrm{~min}$ in PBS-T. Cover- slips were mounted with ProLong Gold antifade mountant with 4',6-diamidino-2-phenylindole (Invitrogen, San Diego, CA). Primary antibodies used were rabbit anti-Tph2 (1:500; Millipore, Bedford, MA) and rabbit anti-5-HT (1: 500; ImmunoStar, Hudson, WI), and the secondary antibody used was goat anti-rabbit Alexa 594 (Invitrogen). Coronal brain sections containing regions of interest were selected based on established boundaries (Paxinos and Franklin, 2000). Sections were imaged on a Zeiss LSM510 confocal microscope or a Zeiss Axioskop II MotPlus. Digital inversion of the images in grayscale and brightness/ contrast adjustments were made in Adobe Photoshop equally for images within panels as noted (see Fig. 2).

\section{HPLC}

Tissues from mice in cohorts 2 and 3 were prepared for HPLC analysis following established protocols (LerchHaner et al., 2008). Mice were anesthetized with Avertin and perfused with $10 \mathrm{U} / \mathrm{ml}$ heparin (Sigma-Aldrich, St. Louis, MO) in cold PBS for $\sim 6$ min to clear the brain of blood and remove confounding peripheral 5-HT. Brains were immediately removed and placed on dry ice. When they were partially frozen, the brains were cut at bregma $-2.92 \mathrm{~mm}$ to separate the forebrain and then again directly posterior to the olfactory bulbs. The forebrain and olfactory bulbs were immediately frozen on dry ice. Samples were shipped to the Neurochemistry Core of the Vanderbilt Brain Institute for processing and HPLC analysis of 5-HT and 5-hydroxyindoleacetic acid (5-HIAA) levels.

\section{Quantitative PCR}

Mice from cohorts 2 and 3 were anesthetized with Avertin and perfused with $10 \mathrm{U} / \mathrm{ml}$ heparin (Sigma-Aldrich) in cold PBS for $\sim 6 \mathrm{~min}$. Brains were immediately removed and placed on dry ice. When they were partially frozen, the brains were cut at bregma $-2.92 \mathrm{~mm}$ and $-5.68 \mathrm{~mm}$ to isolate midbrain tissue, which contains the DRN. With the section in a petri dish on a cold plate, a 1.5-mm tissue punch was made at midline, directly ventral to the third 


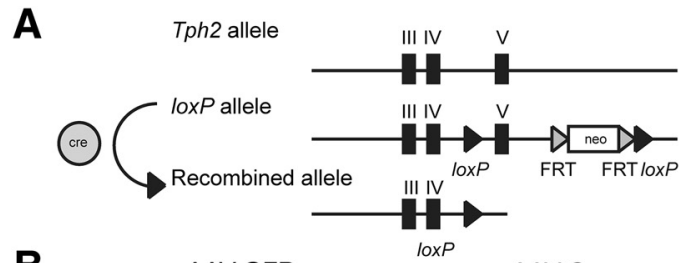

B
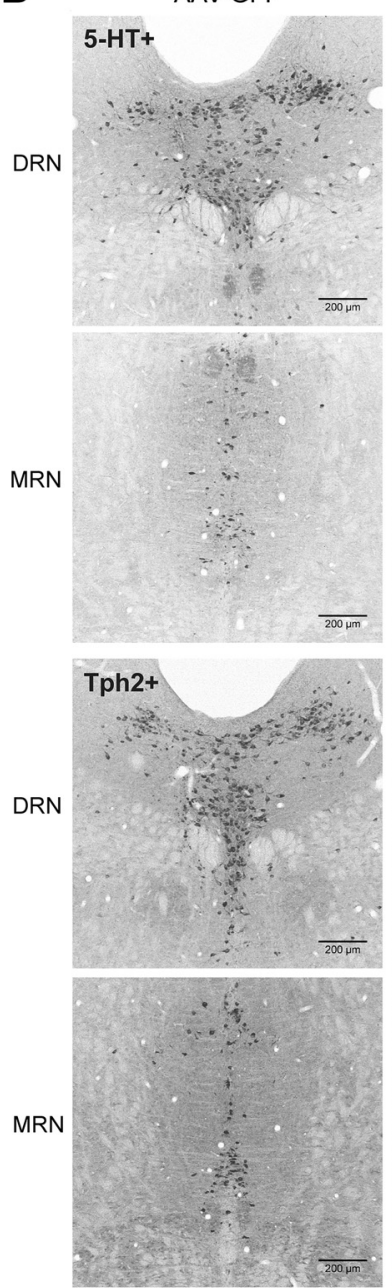

AAV-Cre
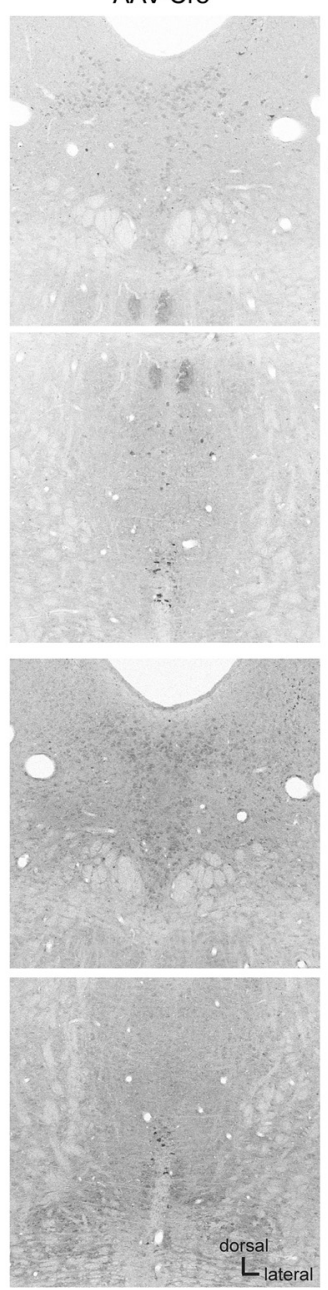

C
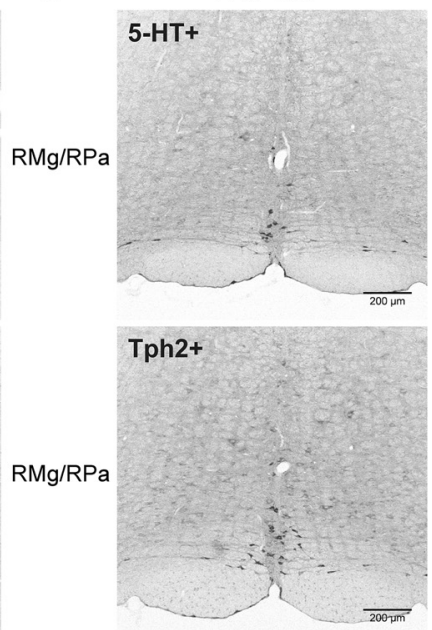

D

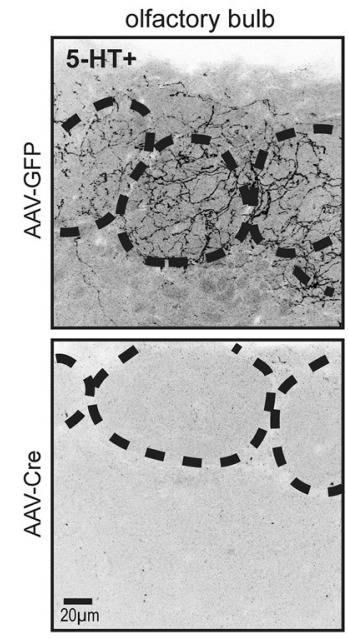

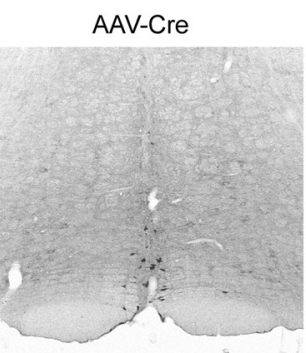

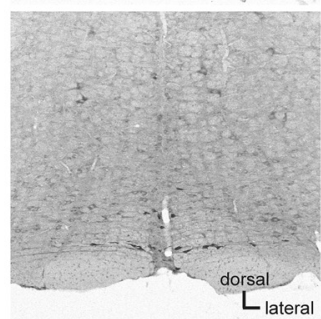

piriform cortex

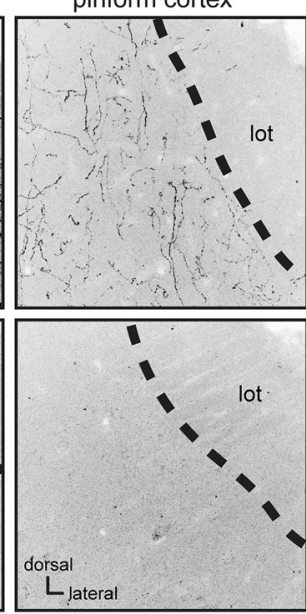

Figure 2. Targeting of Tph2 in the brains of adult mice. A, Schematic of wild-type Tph2 allele (top), floxed allele with exon $V$ flanked by lox $P$ sites (middle), and targeted allele after Cre-mediated deletion of exon V (bottom). B, Representative images of Tph2 ${ }^{\text {fl/fl }}$ mice confirming near-complete loss of 5-HT and Tph2 immunoreactivity within the MRN and DRN of AAV-Cre-treated mice. $\boldsymbol{C}$, Representative images of $T p h 2^{f l / f l}$ mice illustrating the preservation of $5-\mathrm{HT}-$ and Tph2-immunostained neurons in the medullary raphe, including the raphe magnus $(\mathrm{RMg})$ and raphe pallidus (RPa) in AAV-Cre-treated mice. The raphe magnus does not send many fibers into the forebrain or olfactory structures specifically, but instead largely projects into the spinal cord (Bowker et al., 1981; Skagerberg and Björklund, 1985). D, Representative images of $T p h 2^{f / f l}$ mice confirming near-complete loss of $5-\mathrm{HT}$ immunoreactivity within both the main olfactory bulb and piriform cortex in AAV-Cre-treated mice. Images are from stacks of 1.2- $\mu \mathrm{m}$-thick confocal images. Dashed lines in olfactory bulb images represent borders of glomeruli identified with nuclear counterstain (not shown), and in piriform lines, the border of the lateral olfactory track (lot) form layer i of the piriform. Images are from coronal sections, $20 \mu \mathrm{m}$ thick. Images have been converted to monochrome and inverted. Contrast/brightness adjustments were equally applied to images in $\boldsymbol{B}$ and $\boldsymbol{C}$ to optimally display immunostained cell bodies. Contrast/ brightness adjustments were equally applied to images in $\boldsymbol{D}$ to optimally display immunostained fibers.

ventricle, to isolate the DRN. Tissue punches were lysed and homogenized using a $1-\mathrm{mL}$ dounce homogenizer, from which RNA was isolated using a PureLink RNA Mini Kit (Invitrogen). RNA was quantified using a NanoDrop 2000 (Thermo Fisher Scientific, Waltham, MA). RNA (244 ng) from each sample was used for reverse transcription to cDNA with a Transcriptor First Strand cDNA Synthesis
Kit (Roche, Basel, Switzerland). Tph2 and Actb levels were quantified by quantitative PCR (qPCR) using TaqMan Fast Advanced Master Mix with TaqMan Gene Expression Assays for Tph2 (Mm00557715_m1) and Actb (Mm00607939_s1; Applied Biosystems, Foster City, CA). The reactions were run in triplicate using a StepOnePlus system (Applied Biosystems), and relative expression val- 
ues were calculated by StepOnePlus software with Tph2 levels normalized to $\beta$-actin expression.

\section{Behavior}

Mice used for olfactory go/no-go testing (cohorts 2 and 3; Fig. 1) were allowed 3 weeks to recover from surgery before any behavioral testing began. This duration also provided sufficient time for the AAV transduction and AAV-Cre-mediated targeting of brain Tph2 (see Results). Baseline body weights were collected from all mice, and the mice were placed on a 24-h water restriction schedule with water available every $24 \mathrm{~h}$ in a small dish on their cage floor and/or in the context of behavioral task performance. We used a standard $80-85 \%$ body weight (from baseline weight) to ensure motivation in the operant water-motivated task (Slotnick and Restrepo, 2001). This level of weight loss is mild, and the mice appeared healthy (well-groomed fur, regular food intake) and active. After reaching $80-85 \%$ of baseline weight, mice were acclimated to the go/no-go operant boxes. Mice were singlehoused for all behavioral procedures, and all testing occurred during the light phase of the cycle $(0900$ to $1800)$. All behavior was carried out in a dimly lit, wellventilated room at $20-22^{\circ} \mathrm{C}$.

We used three custom-built go/no-go operant chambers designed based on the work of Bodyak and Slotnick (1999) and Slotnick and Restrepo (2001). The chambers were constructed of quarter-inch-thick acrylonitrile butadiene styrene (ABS) plastic and custom 3D-printed [polylactic acid (PLA)] nose-poke ports. The inner dimension of the chamber was $6 \times 6$ inches, with 11-inch-tall walls. On one wall was an operant plate consisting of two holes housing the two nose-poke ports (Fig. 3A). The nose-poke ports were three-quarter-inch inner diameter and were positioned 2 inches apart (center to center); each was 1.25 inches above the chamber floor (from floor to center of port). On another wall of the operant chamber was a hinged door allowing placement and removal of the mice. The chambers were open-top (no ceiling), to facilitate air circulation. The top of the odor port terminated into a flexible air hose (1-inch diameter) which was connected to a 12-V computer fan, which drew air from within the chamber (through the poke hole) up through the fan. An infrared LED and infrared photodetector were placed $\sim 2$ $\mathrm{mm}$ into each port to provide continuous measures of port entry (beam interruption). The chambers were each housed in a single wooden enclosure box with an 8-inchwide 12-V computer fan on one wall of the enclosure and a vent hole on the other to ensure that air could freely circulate throughout the chamber and facilitate odor elimination from within. All valves, computer hardware, and odor vials were housed outside of the enclosure boxes, which were positioned on a stainless steel rack.

Odor solenoid valves (Parker Hannifin, Cleveland, $\mathrm{OH}$ ) and reward pinch valves (NResearch, West Caldwell, NJ) were controlled by custom code written in Tucker-Davis Technologies software (Alachua, FL), which gated voltage through a relay driver module (LabJack Corp., Lakewood, $\mathrm{CO}$ ). The status of the infrared nose-poke beams as well as valve activity (odor or reward) was relayed into a digital processor (Tucker-Davis Technologies) and acquired to a computer at $3 \mathrm{kHz}$ sampling rate.

Mice were shaped in the go/no-go task across four phases (Bodyak and Slotnick, 1999; Slotnick and Restrepo, 2001). In phase 1, upon nose-poke into the odor port (in absence of odor), the mice were allowed to withdraw and then nose-poke into the reward port in exchange for the water reward $(\sim 3 \mu \mathrm{l})$. For the first two blocks of this, to facilitate task acquisition, the nose poke into the odor port automatically triggered water reward release, without the need for the animal to even poke within the reward port. Throughout phase 1, the duration required for the mouse to hold its nose in the port (break the beam) was gradually increased from 200 to $600 \mathrm{~ms}$ in $200-\mathrm{ms}$ increments. Thus, by the end of phase 1 , the mouse must be holding its nose in the odor port for $600 \mathrm{~ms}$. Upon achieving $\geq 85 \%$ correct responses in two consecutive blocks of 20 trials (criterion performance), the mice were switched into phase 2 of training. In phase 2 , the mice were required to nosepoke for $600 \mathrm{~ms}$ and then sustain the poke for an additional $200 \mathrm{~ms}$, during which time a conditioned reward odor (CS+) was delivered $(800 \mathrm{~ms}$ total hold requirement). The CS+ odor was delivered in all trials in which the animal held its nose in the port for $\geq 600 \mathrm{~ms}$. The mice were then gradually required to increase their hold duration to remain with their noses in the port for $400 \mathrm{~ms}$ of CS + odor presentation (1000 ms total hold requirement). Upon achieving criterion performance on phase 2, mice were transitioned to phase 3 , wherein they had to detect the CS+ odor trials versus blank stimulus trials, in which reward delivery in the reward port occurred only upon nose pokes into this port preceded by CS+. During both trials, total hold duration was $1000 \mathrm{~ms}(600 \mathrm{~ms}$, followed by $400-\mathrm{ms}$ stimulus). Withdrawal from the odor port and poking in the reward port during CS+ trials resulted in a water reward. Upon achieving criterion performance on phase 3 , mice were transitioned to phase 4 and shaped on the odor discrimination task. In this, the mice were again required to nose poke in the odor port for a minimum of $1000 \mathrm{~ms}$ (600 ms, followed by 400-ms stimulus). Withdrawal from the odor port and poking in the reward port during CS + trials resulted in a water reward (hit). Delivery of CS + but failure to poke in the reward port within $5 \mathrm{~s}$ was counted as an error (miss). Delivery of a conditioned nonrewarded odor (CS-) and failure to poke in the reward port within $5 \mathrm{~s}$ was counted as a correct reject. Finally, delivery of a CS- followed by poking in the reward port within $5 \mathrm{~s}$ was counted as a false alarm. The percentage of correct responses (hits and correct rejects vs. misses and false alarms) was determined for each block of 20 trials. During phase 4, a minimum 5-s intertrial interval was enforced. Mice were not cued to nose poke but instead were able to self-initiate trials by nose poking beyond the boundaries of the intertrial interval. The intertrial interval could thus be reset after completion of new trials or because of "short samples," wherein the animal failed to maintain nose poke for the required duration. All mice con- 
A

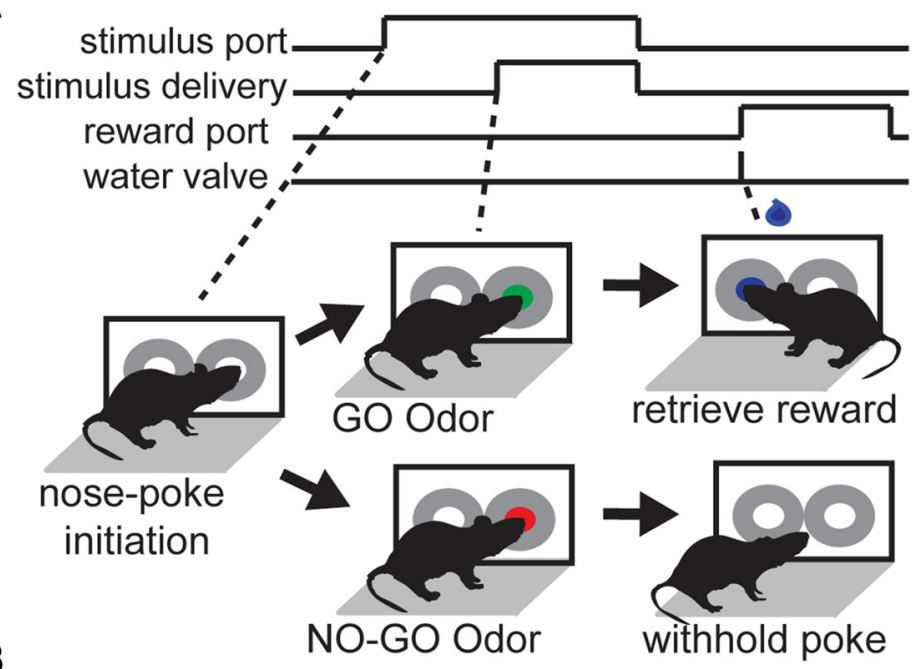

B

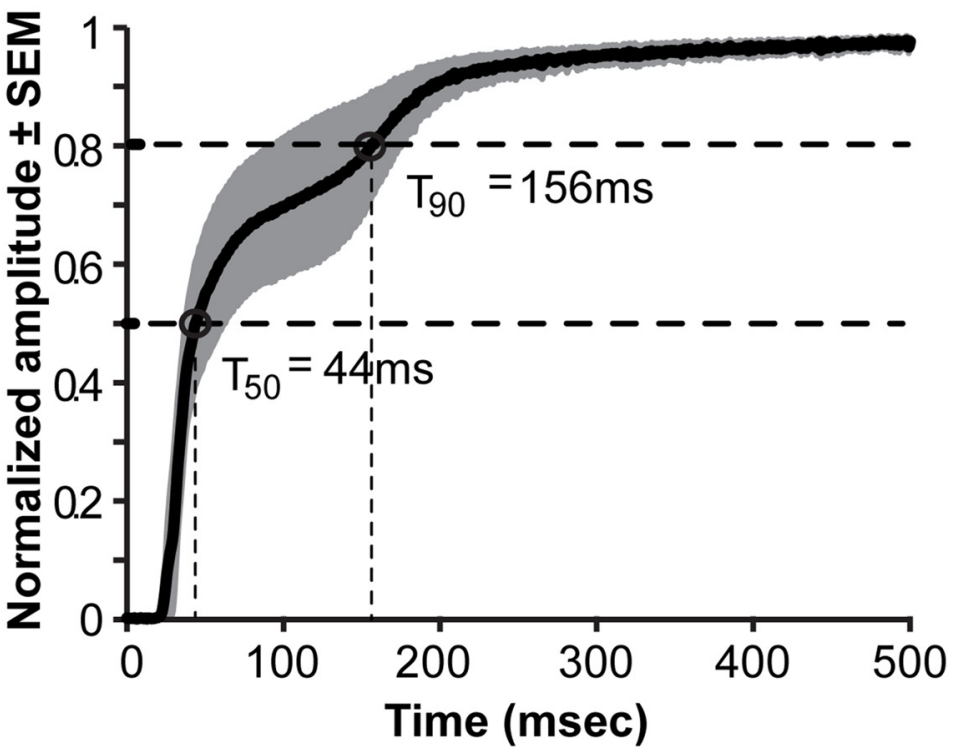

Figure 3. Go/no-go olfactory task design and stimulus control. $\boldsymbol{A}$, Outline of the go/no-go task structure as described in detail in Materials and Methods. In the final stage of the task, mice nose-poke in the right port (600-ms hold duration required), receive either CS + or CS- (400-ms minimum hold [50-ms for self-regulation paradigm]; 2-s maximum hold), and retrieve a reward in the left port (S+ trial) or withhold their response (S- trial). Green shaded circle, presentation of CS+; red shaded circle, presentation of CS-; blue waterdrop icon, brief 3- $\mu \mathrm{L}$ water reward delivery. $\boldsymbol{B}$, Averaged voltage trace from a photoionization detector (PID) to illustrate the rapid odor stimulus dynamics as controlled by the go/no-go olfactometers. Fifteen trials of the odorant, heptanal (see Materials and Methods for intensity used and flow rate), were delivered by each olfactometer while the PID sampling port was positioned in the center of the odor sampling port. Data are normalized to the maximum value acquired by each olfactometer's averaged PID output (over the 15 trials) and plotted as the average across all three olfactometers. Time 0 equals odorant valve onset. Time points of $50 \%$ $\left(T_{50}\right)$ and $90 \%$ rise times $\left(T_{90}\right)$ are indicated. Gray-shaded area indicates SEM. Although these dynamics may vary slightly across odors, this measure illustrates the precision and stability of the odor presentation methods used.

tributing complete phase 4 data in the study were required to complete the same number of blocks $(100 \pm$ $5)$ before going onto the reversal learning task. During the reversal task, the behavioral contingencies for the $\mathrm{CS}+$ and CS- were switched so that the previous CSis now a CS+ (rewarded) and vice versa.

After reversal learning tests, the mice were required to perform in six blocks at or above criterion level (85\%) before engagement in the odor-discrimination self-regulation task, wherein they were mandated to nose poke for only $600 \mathrm{~ms}$ and continue to nose poke for $50 \mathrm{~ms}$ of odor. In this overall testing structure, all mice needed to reach and demonstrate consistent criterion levels of behavior before being transitioned into the subsequent tasks.

Finally, after all olfactory testing, the mice were tested for water motivation on the next day. For water motivation tests, mice were placed in the operant chambers for $1 \mathrm{~h}$, during which each nose poke into the 
odor port (in absence of odor) immediately triggered a reward to be released in the reward port on a fixed ratio 1 schedule.

The operant boxes were cleaned thoroughly with water and $90 \% \mathrm{EtOH}$ between all behavioral sessions and mice and allowed to dry. Mice were tested only once per day.

\section{Stimulus presentation}

Odors were presented through a custom air-dilution olfactometer with independent polytetrafluoroethylene (PTFE) stimulus lines up to the point of entry into the odor port. Odorants included ethyl butyrate, heptanal, isopentyl acetate, (-)-limonene (Sigma-Aldrich), each at their highest available purity $(>97 \%)$ and each diluted to 0.5 Torr vapor pressure in mineral oil. These odors elicit distinct patterns of main olfactory bulb activity (e.g., Johnson et al., 2002), and thus they were selected for our assay of "coarse" olfactory discrimination. Odors and a blank stimulus (mineral oil) were presented at a rate of $1 \mathrm{l} / \mathrm{min}$. Liquid odor $(2 \mathrm{ml})$ was aliquoted into $25-\mathrm{ml}$ glass headspace vials sealed with Teflon septa (Shamrock Glass, Seaford, $\mathrm{DE})$, and air flow through the vials was permitted with 18-Ga s/s needles fit with PTFE lure fittings that terminated into PTFE odor lines (1/16-inch i.d.; Clippard Minimatic, Cincinnati, $\mathrm{OH}$ ). Not all animals were tested with all odors. One cohort of mice used for behavior was initially shaped on one odor pair, whereas the other behavioral cohort was shaped on a different odor pair. The experimenter was not blind to odor assignment, but all stimulus presentation was automated. Rewarded and unrewarded odors were pseudorandomized within each block (10 trials of each CS+ and CS-). The concentrations of odorants were selected to be well above detection thresholds for mice (Bodyak and Slotnick, 1999). Odors were presented until the animal withdrew from the odor port or for a maximum duration of 2000 ms.

\section{Data analysis}

Behavioral data acquired from the operant chambers were extracted in custom code written in Spike2 (Cambridge Electronic Design, Cambridge, UK). Data were extracted by a single experimenter before the unblinding of this experimenter to treatment groups. All statistical tests were performed in StatView (SAS Institute, Cary, NC). Data were pooled across cohorts within measures, organized by treatment group (AAV-GFP vs. AAV-Cre), and confirmed as normally distributed with a Kolmogoro$\mathrm{v}-\mathrm{Smirnov}$ test. Statistical $p$ values are 2-tailed unpaired $t$-tests unless otherwise specified. Values are reported as mean \pm SEM unless otherwise indicated.

\section{Results}

\section{Conditional targeting of adult brain 5-HT synthesis}

Three cohorts of mice were used to validate adult brainspecific Tph2 targeting and test the necessity of adult brain 5-HT in odor-guided learning and olfactory perception (Fig. 1). We used a recently established protocol (Whitney et al., 2016) to specifically target adult brain 5-HT synthesis by stereotaxic injection of an AAV-Cre recombinase vector into mice (Kim et al., 2014) that have
loxP sites flanking the fifth exon of tryptophan hydroxylase $2\left(T p h 2^{f l / f l}\right)$, which encodes the rate-limiting enzyme for the production of $5-\mathrm{HT}$ (Fig. $2 A$ ). In adult Tph2 $2^{f l / f l}$ mice, AAV-Cre or AAV-GFP was injected into the midbrain, where 5-HT neurons of the MRN/DRN are located and project to olfactory structures in the forebrain (McLean and Shipley, 1987; Steinfeld et al., 2015).

In an independent cohort of $T p h 2^{f l / f l}$ mice, we performed anti-5-HT and anti-Tph2 immunostaining to verify the targeting of Tph2 and 5-HT depletion after injection of either AAV-Cre or AAV-GFP into the mice at 6 weeks of age (cohort 1, $n=2$ and 4, respectively; Fig. 2). Analyses performed 2 weeks after injection of AAV-Cre into Tph $2^{f / f l}$ mice indicated a near-complete loss of 5-HT and Tph2 immunoreactivity in the MRN and DRN, compared with AAV-GFP-injected mice (Fig. 2B). In contrast, and as an example of the precision of this approach, 5-HT and Tph2 immunoreactivity were preserved in the medullary raphe, which provide 5-HT innervation to the spinal cord (Bowker et al., 1981; Skagerberg and Björklund, 1985; Fig. 2C). Although virally mediated Cre expression is not restricted to $5-\mathrm{HT}$ neurons, this targeting is specific to the $5-\mathrm{HT}$ system, as Tph2 is only expressed in 5-HT-producing neurons (Walther et al., 2003). Importantly, 5-HT-immunopositive fibers were strikingly absent in major olfactory structures, including in all the cell layers of main olfactory bulb and piriform cortex (Fig. 2D). Particularly in the olfactory bulb, the massive amounts of anti-5-HT fibers originating in the $\mathrm{MRN}$ and terminating in the glomerular layer (McLean and Shipley, 1987; Steinfeld et al., 2015; Suzuki et al., 2015; Muzerelle et al., 2016), the first synaptic processing layer of odor information, were absent in AAV-Cre-injected Tph2 ${ }^{f l / f l}$ mice (Fig. 2D). A rare and isolated 5-HT-immunopositive fiber was observed in occasional AAV-Cre-treated Tph $2^{\text {fl/fl }}$ mouse brain sections, including in the olfactory bulb granule cell layer. Although not shown here, 5-HT fibers were also absent in other olfactory structures, including the olfactory tubercle and anterior olfactory nucleus. Thus, as reported recently (Whitney et al., 2016), treatment of adult Tph ${ }^{f l / f l}$ mice with AAV-Cre achieves a near-complete loss of brain 5-HT, including, as shown here, in the olfactory bulb and piriform cortex.

\section{Learning and performance of adult Tph2-targeted mice in an olfactory go/no-go task}

Having verified a conditional approach for the nearcomplete elimination of 5-HT in the adult forebrain including olfactory structures, we next sought to investigate our main hypothesis that adult brain $5-\mathrm{HT}$ is necessary for essential odor-guided behaviors. There are countless assays available to explore olfactory perceptual function in mice. We selected the well-established, nose-pokebased olfactory go/no-go task (Bodyak and Slotnick, 1999; Slotnick and Restrepo, 2001) based on Pfaffmann et al. (1958) (Fig. 3). This operant task requires waterrestricted mice to perform an instrumental watermotivated response to a conditioned odor; throughout conditioning, the behavior of the animal is motivated by thirst versus odor-specific motivation. This is important, 
since odor-specific motivation may alter odor investigatory dynamics (sniffing), a variable that may be compounded by $5-\mathrm{HT}$ manipulations, which may modulate motivated behavior (Liu et al., 2014). In the go/no-go task, animals must learn to engage in the operant behavioral sequence of nose poking into an odor port to allow the possibility of receiving a $3-\mu$ l drop of water from the neighboring reward port. Reward delivery in the reward port occurs only upon nose pokes into this port preceded by the conditioned rewarded odor (CS+), but not the conditioned unrewarded odor (CS-; Fig. $3 A$ ). CS+ and CS- odor trials occurred in a pseudorandom order throughout all testing sessions.

Training in the go/no-go task occurs over four phases (see Materials and Methods), and thus a potential initial hurdle in our investigation into the olfactory behavior of $5-\mathrm{HT}$-depleted mice was shaping them to criterion performance ( $\geq 85 \%$ correct responses in two consecutive blocks of 20 trials). Indeed, $5-\mathrm{HT}$ is considered a potent modulator of odor learning in neonatal rats (McLean et al., 1993). As before, 6-week-old adult $T p h 2^{f / / f l}$ mice (cohorts 2 and 3) were injected with AAV-GFP or AAV-Cre into the midbrain DRN/MRN region. Mice were placed on a mild 24-h water restriction schedule at 23-29 d post-treatment to allow sufficient time for the near-complete elimination of brain 5-HT levels before shaping on the task started (see timeline in Fig. 1). One AAV-Cre-treated mouse was eliminated from all data analysis and statistical reports after both 5-HT HPLC and Tph2 qPCR results that revealed intact brain $5-\mathrm{HT}$ and Tph2 levels, likely because of imprecise AAV injection.

Impressively, all remaining mice in the AAV-GFP $(n=9)$ and AAV-Cre $(n=8)$ treatment groups were able to learn the go/no-go task (Fig. 4). Tph2-targeted mice required a similar number of training blocks as control mice to learn reward retrieval in phase 1 (Fig. $4 A ; t(15)=-0.655, p=$ 0.522 ), sampling of the CS+ odor in phase 2 (Fig. $4 B ; t(15)$ $=-0.028, p=0.978)$, and odor detection of the CS + odor from a blank stimulus in phase 3 (Fig. $4 C ; t(15)=$ $-0.724, p=0.480$ ). When learning to discriminate the CS+ odor from a CS- odor in phase 4, Tph2-targeted mice required significantly more training blocks to reach performance criterion (Fig. $4 D ; t(15)=3.507, p=0.003$ ). However, this finding was largely attributable to longer learning latencies in just two of the eight AAV-Cre mice, which eventually exceeded the criterion threshold (Fig. $4 D$, downward arrowheads).

With both groups of mice having learned the go/no-go task, we next allowed them to perform in the odor discrimination phase over multiple successive daily sessions (five to nine sessions) for a total of 2000 trials each (100 blocks/mouse). This total, 100 blocks of performance, was selected as a behavioral milestone to allow a large sampling of behavior from all animals and ensure extensive, as well as equivalent, task experience before engaging in the reversal learning paradigm. One AAV-Cre- and one AAV-GFP-treated mouse were eliminated from this and further data acquisition because of complications occurring within the 2 weeks of behavioral shaping, which impaired performance in the task (see Fig. 1). As shown in
Fig. 4E, the remaining AAV-Cre-treated mice achieved similar behavioral performance as AAV-GFP-treated mice on the odor discrimination task, whether the mandatory odor sampling time was fixed at $400 \mathrm{~ms}(t(13)=-1.073, p$ $=0.306$ ) or was self-regulated in a less restricted task structure (see Materials and Methods) performed across 15 blocks on subsequent sessions $(t(13)=-1.486, p=$ $0.161)$. Similarly, over the course of the first 15 blocks of criterion performance, AAV-Cre mice sampled odors, measured as the time from odor onset to withdrawal from the sampling port, for similar durations compared to AAVGFP mice (Fig. 4F), in both the original odor discrimination task $(t(13)=0.577, p=0.574)$ and when odor sampling was self-regulated $(t(13)=1.358, p=0.198)$. Thus, while both groups sampled odors for qualitatively less time in the self-regulated task compared to the original fixed odor sampling sessions (Fig. 4F, right vs. left), AAV-Cre mice maintained odor discrimination accuracy and odor sampling times similar to those of AAV-GFP mice on both task structures.

In a separate session, we sought to confirm that the mice were indeed relying on olfactory cues to perform the go/no-go task. In this experiment, a subset of mice $(n=7)$ shaped to criterion performance on the CS + versus CSphase 4 odor discrimination task were tested for their reliance on the odors to make correct responses. After two blocks of CS + versus CS- odor discrimination (Fig. $4 G$, shaded), the experimenter disconnected the odor input lines to the odor ports of the operant chamber (Fig. $4 G$, unshaded). The reduced performance on block 3 and proceeding into block 4 falls within chance levels $(<60 \%$ correct responses) in all mice. At block 5 , the experimenter reconnected the odor lines, and the performance of the mice gradually returned (Fig. 4G, shaded). This illustrates that the mice were indeed using the odors to guide their behaviors, not other cues that may be associated with the operant chamber function (valve clicks, air flow, etc.).

\section{Gross motor control, water intake, body weight, and water motivation of Tph2-targeted mice}

To identify any additional factors that may influence go/no-go task performance in adult Tph2-targeted mice, we performed further measures on the mice (cohorts 2 and 3 ) either during task engagement or after completion of all olfactory testing. First, we measured gross motor control during task performance as assayed by the average duration of withdrawal from the odor port until nose poke in the reward port in phase 4 odor discrimination testing (Fig. 5Ai) and during the self-regulation odor discrimination testing (Fig. 5Aii). These data revealed that Tph2-targeted mice maintained coordinated performance (nose poking and movement between ports) in both phase $4(t(15)=1.809, p=0.198)$ and the self-regulation testing $(t(13)=0.548, p=0.593)$ compared to the AAV-GFP treated mice.

We also monitored body weights and fluid intake of the water-restricted mice. AAV-Cre- and AAV-GFP-treated mice began water restriction at statistically similar baseline body weights (Fig. $5 B ; t(15)=-1.456, p=0.165$ ). 

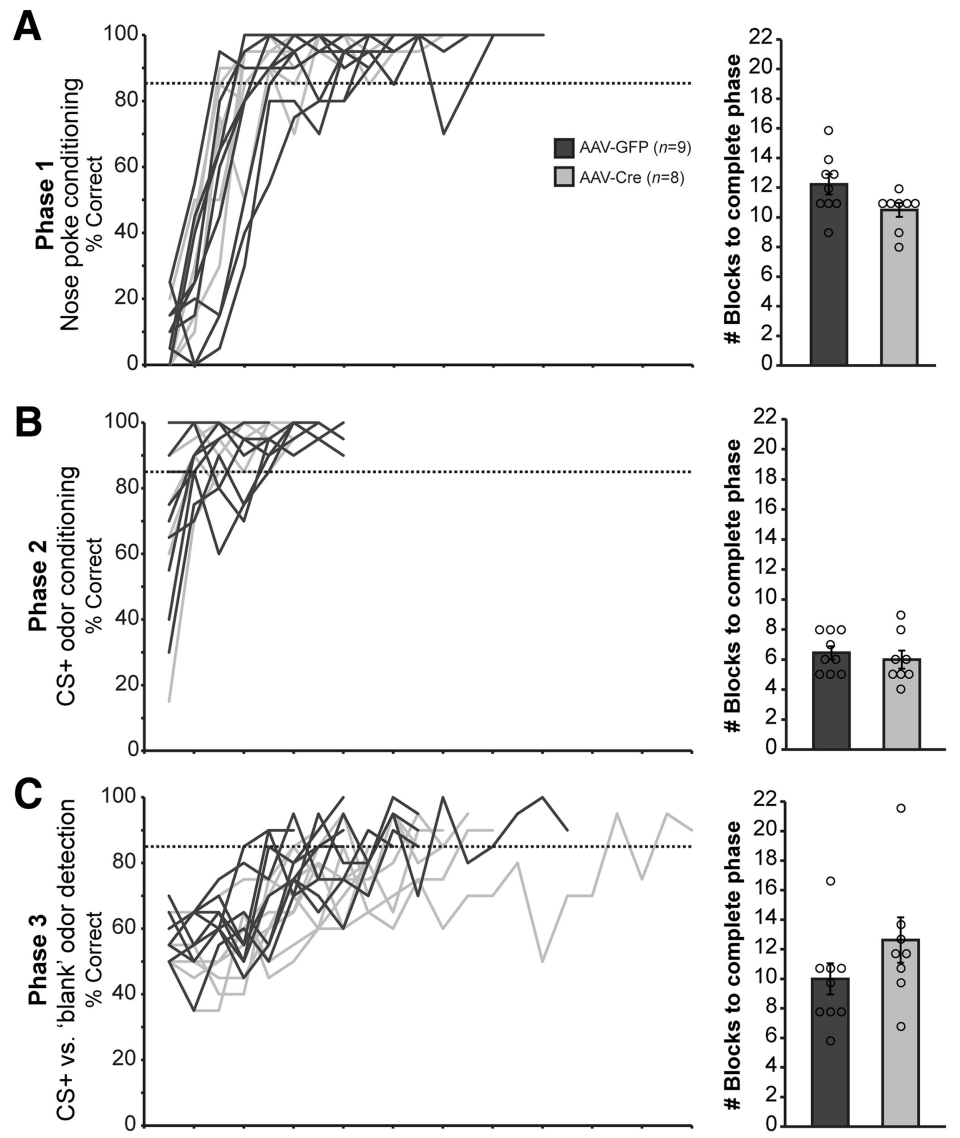

\section{E}
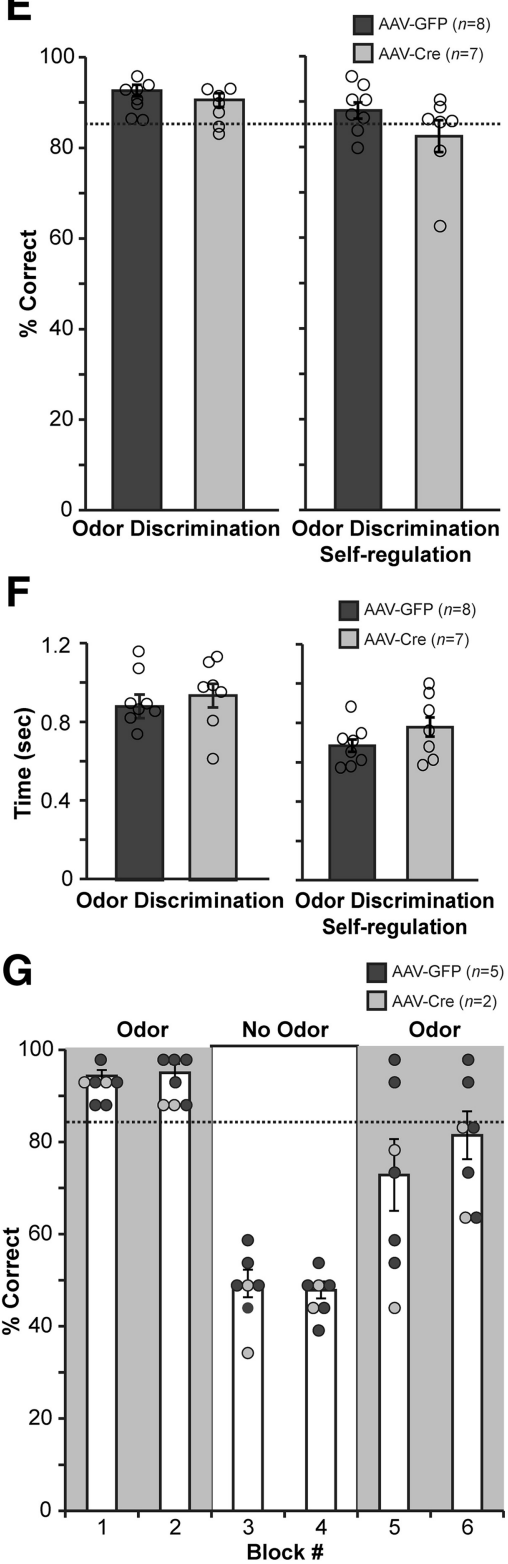

Figure 4. Adult Tph2-targeted mice learn the olfactory go/no-go task and display similar levels of odor acuity and odor sampling durations. $\boldsymbol{A}-\boldsymbol{D}$, Learning curves (left) and total number of blocks required to complete each phase (right) across phases 1-4. $* * p<$ 0.005. $\boldsymbol{E}$, Average block percent correct performance during the odor discrimination task when odor sampling time was fixed (left, 2000 trials/mouse) and self-regulated (right, 300 trials/mouse). F, Average sampling durations (nose poking during odor on) for CS+ and CS- odors during phase 4 odor discrimination (blocks $\geq 85 \%, 300$ trials/mouse, left), and during self-regulation of odor discrimination (blocks $\geq 85 \%, 300$ trials/mouse, right). $\mathbf{G}$, Odor-removal control experiment to demonstrate the reliance of the mice on the odor stimuli to engage in the go/no-go task. Data are mean \pm SEM of all mice/block. Dots: individual mouse data.

Importantly, all mice were maintained at statistically similar body weights throughout go/no-go task performance (Fig. 5C, F; $t(15)=-0.043, p=0.966)$. Further, we measured the amount of water provided to the mice after behavioral testing each day to maintain appropriate body weights (as shown in Fig. 5C). Each day, the experimenter provided supplemental water to the water-restricted mice (in addition to what they received upon making correct decisions). AAV-Cre-injected mice required more water than AAV-GFP-injected mice to maintain $80-85 \%$ body weight levels throughout the duration of experimentation
(Fig. $5 D ; t(15)=3.913, p=0.0014$ ). Pilot experiments (not included in Fig. 1) in which we provided AAV-Cre-injected mice with the same levels of water as AAV-GFPinjected mice revealed excessive weight loss in AAVCre-injected mice (data not shown), and therefore we established the paradigm of providing AAV-Cre-treated mice with additional supplemental water each day to ensure that mice in both treatment groups fell within a similar operational definition for thirst.

Finally, on a separate day (see Fig. 1), mice were placed in the operant chambers for a test of water motivation 

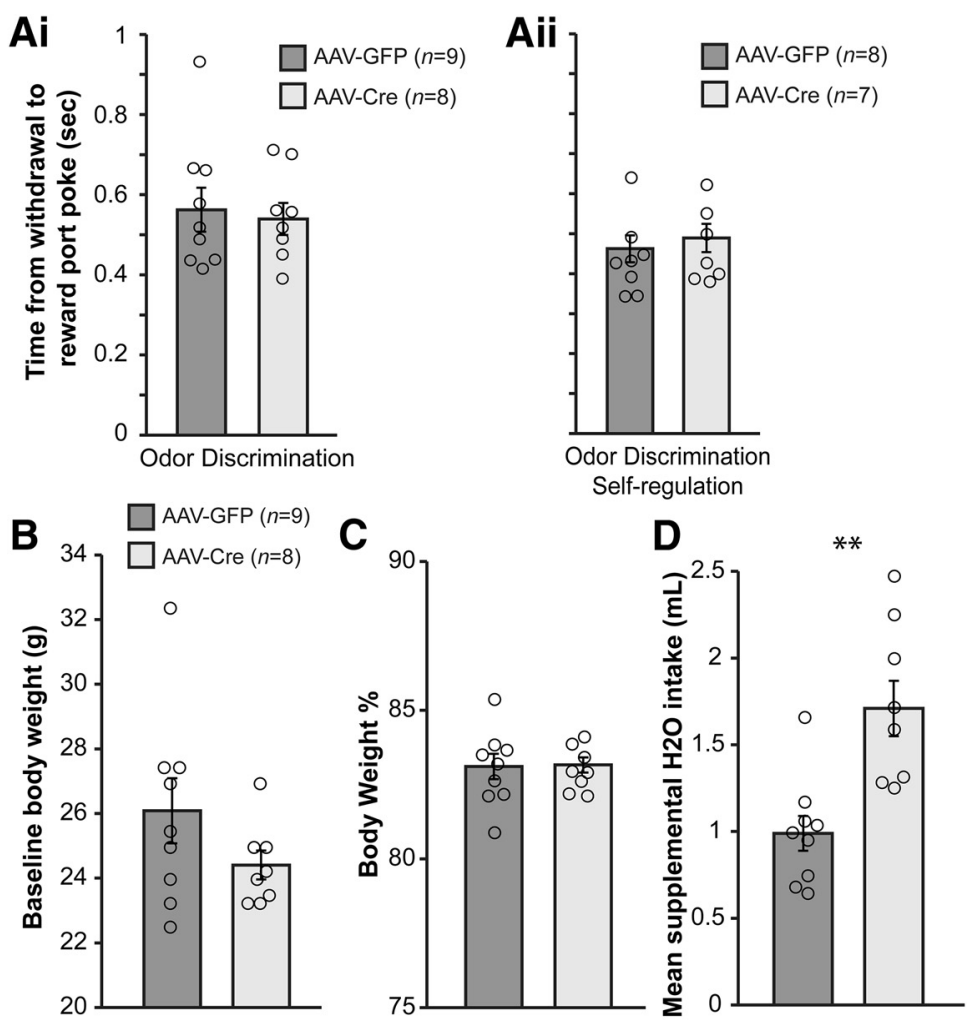

\section{Ei}

\section{Eii}
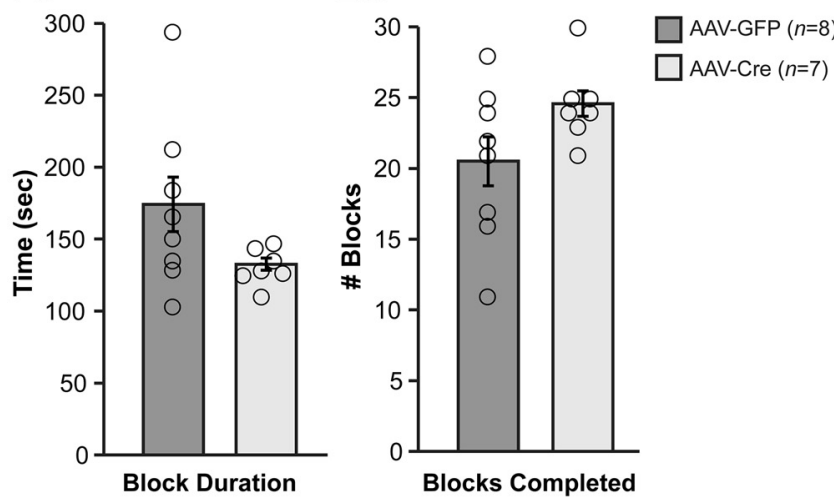

Figure 5. Gross motor performance, body weights, water intake, and water motivation of AAV-GFP- and AAV-Cre-treated Tph2 $2^{\text {fl/fl }}$ mice during the go/no-go task. $\boldsymbol{A}$, Average duration of withdrawal from odor port to nose poke in the reward port during phase 4 odor discrimination ( 15 blocks $\geq 85 \%, 150 \mathrm{CS}+$ trials/mouse; $\boldsymbol{A} \boldsymbol{i}$ ) and the self-regulation odor discrimination testing (15 blocks $\geq 85 \%, 150$ $\mathrm{CS}+$ trials/mouse; $\boldsymbol{A}$ ii). $\boldsymbol{B}$, Baseline body weights of mice used in olfactory go/no-go testing before water deprivation. $\boldsymbol{C}$, Mean body weights of all mice (averaged across all days of behavioral testing, range 21-24 days) expressed as percentage of weight (during water restriction) as a function of baseline weight $(\boldsymbol{A})$. $\boldsymbol{D}$, The mean of supplemental water for each mouse across all testing days. $\boldsymbol{E}$, Water motivation test results. Histograms of the average block duration (11-30 blocks/mouse; EI) and the number of blocks completed in a single 1-h session of the water motivation test (Eii). Data are mean \pm SEM of all mice. Dots: individual mouse data. $* * p<0.005$.

lasting $1 \mathrm{~h}$. In this task, each nose poke into the odor port (in absence of odor) immediately triggered a reward to be released in the reward port, and, thus, this task allowed free access to water and quantification of water motivation. AAV-Cre-treated mice completed trial blocks with similar latencies (Fig. 5Ei; $t(13)=-1.762, p=0.102$ ) and completed a similar number of blocks (Fig. 5 Eii; $t(13)=$ $1.76, p=0.102)$ compared to AAV-GFP-treated mice. Together, these data from the above control measures suggests that "non-olfactory" behaviors of Tph2-targeted mice during engagement in the go/no-go test are not confounded by differences in the ability of these mice to execute coordinated motor behaviors or by altered levels of water motivation.

\section{Preserved higher-order odor-guided behaviors in Tph2-targeted mice}

We next sought to explore the ability of Tph2targeted mice to engage in higher-order olfactorybased behaviors. Reversal learning is a cognitive ability 
A

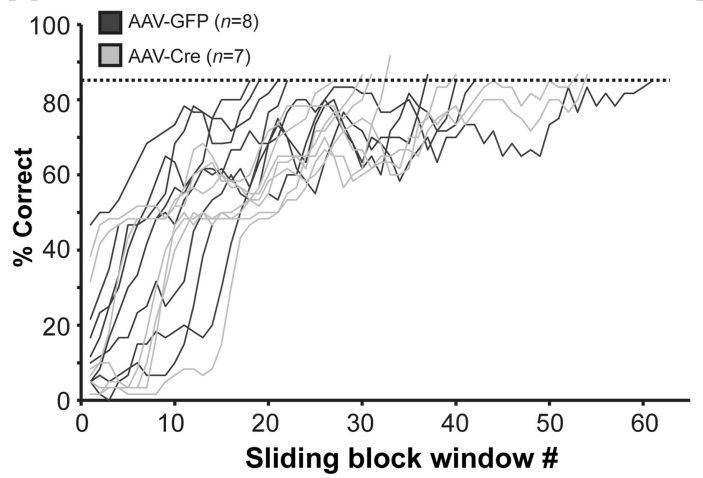

B

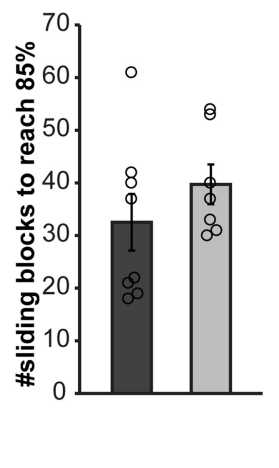

Figure 6. Adult brain 5-HT synthesis is not required for olfactory reversal learning. $\boldsymbol{A}$, Learning curves during odor-pair reversal, plotted with a three-block average sliding window until each mouse reached or surpassed $85 \%$ correct responses. $\boldsymbol{B}$, Average number of sliding blocks to reach $\geq 85 \%$ correct. Circles: values for individual mice.

that is often explored in the context of learning and memory studies. Being reliant on the basic function of odor detection and identification, odor reversal learning, wherein the behavioral contingencies between the CS + and CS- odors are switched so that the previously unrewarded odor is rewarded and vice versa, is a commonly used paradigm (Macrides et al., 1982; Schoenbaum et al., 1999; Sokolic and McGregor, 2007). 5-HT is considered in some contexts to be essential for odor learning (McLean et al., 1993) and cognitive flexibility (Lapiz-Bluhm et al., 2009; Coccaro et al., 2011). Thus, while not specifically assaying olfactory perception, we next investigated reversal learning to explore whether this function of olfactory sensory-dependent cognitive flexibility is impaired in 5-HT-depleted mice.

We reversed the CS+ and CS- behavioral contingencies and monitored the responses of both AAV-GFP $(n=$ $8)$ and AAV-Cre mice $(n=7)$ over successive daily sessions (Fig. 6A; all mice from cohorts 2 and 3 ). As was the case for the initial learning of the go/no-go task (Fig. $4 A-D)$, both groups of mice displayed similar learning curves to acquire the reversal (Fig. $6 A$ ), with interanimal variability present in both groups. To reduce bin noise, learning curves were plotted and analyzed from sliding block window averages over three successive blocks. AAV-GFP- and AAV-Cre-injected mice required a similar number of sliding blocks to acquire the reversal to criterion level (Fig. $6 B ; t(13)=1.067, p=0.305$ ). Thus, at least in this context, mice maintain cognitive flexibility in the absence of adult brain $5-\mathrm{HT}$.

\section{Confirmation of 5-HT synthesis deficiency in mice with perseverant olfactory behaviors and evidence that residual brain 5-HT does not contribute to go/ no-go behavior}

We next verified loss of Tph2 expression in the DRN of AAV-Cre-injected Tph2 $2^{f / f l}$ mice used for the go/no-go testing (cohorts 2 and $3, n=9$ AAV-GFP and $n=8$ AAV-Cre). Analysis of these mice demonstrated that this targeting approach resulted in a $98.01 \%$ decrease in Tph2 mRNA in the DRN $(t(15)=11.254, p<0.0001$, AAV-Cre vs. AAV-GFP mice; Fig. 7A). Further, the brain of each
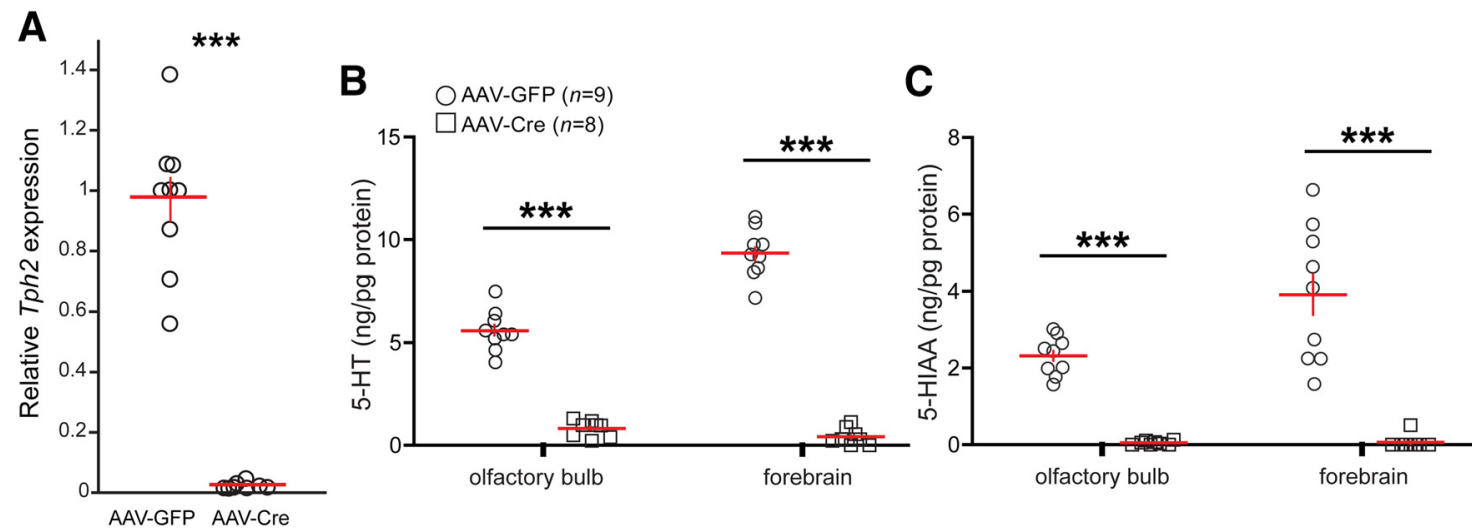

Figure 7. Confirmation of Tph2 targeting and 5-HT depletion in cohorts used for behavior experiments. A, qPCR results displaying a significant reduction in Tph2 expression, relative to Actb, in the DRN region of Tph2 ${ }^{\text {fl/fl }}$ mice injected with AAV-Cre $(n=8)$ compared with untreated controls $(n=9)$. $* * * p<0.0001$. Data are from mice in cohorts 2 and 3. HPLC-quantified levels of 5-HT (B) and 5-HIAA (C) in the olfactory bulbs and forebrain of the same mice used for go/no-go behavior (cohorts 2 and 3 ). Tissue were collected immediately after the completion of the last behavioral measure (water motivation, Fig. $5 E$ ). Data are mean \pm SEM. Individual points: individual mice. $* * * p<0.0001$. 
mouse was collected to confirm the depletion of 5-HT (n $=9$ AAV-GFP and $n=8$ AAV-Cre). HPLC analysis confirmed robust depletions of $5-\mathrm{HT}$ and in its main metabolite, 5-HIAA, in both olfactory bulb $(5-\mathrm{HT}, t(15)=12.588$, $p<0.0001$; 5-HIAA, $t(15)=12.519, p<0.0001)$ and forebrain $(5-\mathrm{HT}, t(15)=19.847, p<0.0001 ; 5-\mathrm{HIAA}, t(15)$ $=6.043, p<0.0001$; Fig. 7B, C).

As we have presented (Figs. 2 and 7), this approach yielded near-complete eliminations of forebrain and olfactory bulb 5-HT. Whereas highly significant reductions in 5-HT were present in AAV-Cre-injected mice compared with AAV GFP mice across all animals in the olfactory bulb and forebrain, some 5-HT remained. Does the residual 5-HT-that is, the minor amount found in the olfactory bulbs or forebrain after AAV-Cre injection-contribute to odor discrimination as assayed here? To test this, we compared, within AAV-Cre-injected animals, the HPLCdetermined concentration of residual 5-HT in both olfactory bulb and forebrain homogenates (same data as in Fig. $7 B$ ) to that of each animal's percentage of correct responses [computed across 2000 trials (same data as in Fig. 4E)]. Again, supporting the notion that the olfactory system does not need 5-HT for its basic function, no relationship was observed between residual $5-\mathrm{HT}$ in either the olfactory bulb (Pearson's $r=0.321, p=0.483, n=7$ ) or forebrain (Pearson's $r=0.0964, p=0.837, n=7$ ) and the percentage of correct responses.

\section{Discussion}

In the present study, we sought to address the longstanding question: Do mammals need 5-HT for olfaction? More specifically, without adult brain 5-HT, do animals possess deficits in the most basic elements of olfactoryguided behaviors? The olfactory system is innervated by numerous neuromodulatory systems. These systems, including dopamine, acetylcholine, and, as explored herein, 5-HT, are hypothesized to provide critical refinements to the function of the olfactory system within the olfactory bulb, as well as in secondary and tertiary olfactoryprocessing stages (Linster and Fontanini, 2014). For instance, multiple lines of elegant work have revealed that cholinergic modulation within the olfactory bulb and downstream piriform cortex impacts fine odor discrimination, short-term odor memory, odor-based rule learning, and odor habituation (Ravel et al., 1992; Saar et al., 2001; Fletcher and Wilson, 2002; Linster and Cleland, 2002; Mandairon et al., 2006; Chaudhury et al., 2009). Despite intense interest in understanding serotonergic modulation of olfactory sensory input, surprisingly few studies have addressed the necessity of 5-HT in olfactory-guided behaviors in the intact animal. In one study, the serotonergic neurotoxin 5,7-dihydroxytrypmaine (5,7-DHT) was used to destroy 5-HT axonal inputs to the rat olfactory bulb (Moriizumi et al., 1994). The authors reported that 5,7DHT-treated rats, trained to avoid cycloheximide in drinking water, became anosmic after neurotoxin treatment (Moriizumi et al., 1994). However, the behavioral assay was not specific for olfaction, and the reported behavioral impairment did not occur until several weeks after depletion of 5-HT immunoreactivity in the bulb. Moreover, the timing of anosmia was correlated with glomerular atrophy that also occurred a few weeks after 5,7-DHT treatment, suggesting that the behavioral deficits were not the result of 5-HT deficiency but rather long-term toxic effects of 5,7-DHT on olfactory structures. A different group reported that 5,7-DHT-based denervation of centrifugal raphe input to the rat neonatal olfactory bulb is required for odor learning and memory and concluded a functional role of 5-HT in this context (McLean et al., 1993). However, in $L m x 1 b$-deficient mice, in which $5-\mathrm{HT}$ neurons fail to differentiate and 5-HT synthesis is genetically blocked permanently at embryonic day 10.5 , olfactory function remains intact (Liu et al., 2011b). The selective serotoninreuptake inhibitor, fluoxetine, rescued deficits in olfactory acuity brought about in mice chronically treated with corticosterone but impaired olfaction when chronically administered to corticosterone-free mice (Siopi et al., 2016). Thus, the significance of 5-HT itself, specifically in the adult brain for odor-guided behaviors and also olfactory perception, is unclear. This void in part comes from a lack of methods to specifically target adult brain 5-HT synthesis.

In this study, we used a sensitive olfactory go/no-go test and conditionally targeted Tph2 with AAV-Cre injections in the adult brain to specifically block 5-HT synthesis, thus avoiding potential off-target effects of pharmacological approaches. The olfactory go/no-go test is a sensitive assay of olfactory function, and qualitatively, mice in our task learned and performed within ranges reported by other groups (Bodyak and Slotnick, 1999; Kelliher et al., 2003; Abraham et al., 2004; Lin et al., 2004; Pho et al., 2005; Wesson et al., 2006). Although the targeting of Tph2 caused a nearly complete elimination of 5-HT synthesis, this deficiency does not result in loss of 5-HT neuron cell bodies, as evidenced by their intact expression of aromatic amino acid decarboxylase (Whitney et al., 2016). The conditional genetic approach left intact early 5 -HT signaling and thus did not interfere with 5-HT's effects on sensory system organization and development (Cases et al., 1996; Gaspar et al., 2003; Toda et al., 2013). Further, this approach avoids potential but presently unknown compensatory mechanisms (Whitney et al., 2016) that might occur in response to 5-HT deficiency in the developing nervous system. The blockade of adult 5-HT synthesis did result in a significant and robust phenotype of altered water motivation (Fig. 5) and has been shown to impact activity levels and circadian rhythms (Whitney et al., 2016). However, in view of the profound effects of serotonergic function on olfactory circuitry, the present results were unexpected, as they indicate that adult brain $5-\mathrm{HT}$ is not necessary for odor learning, coarse odor discrimination, or normal coordinated odor-guided behavior (sampling durations, Fig. 4F). Further, we found that Tph2-targeted mice were able to successfully complete a reversal learning task (Fig. 6). This finding was also surprising, as a significant number of studies using a range of approaches to alter 5-HT function and then assess behavioral outcomes in rodents, nonhuman primates, and humans have repeatedly suggested that reduced brain 5-HT levels hinder reversal learning 
(Murphy et al., 2002; Masaki et al., 2006; Bari and Robbins, 2013; Izquierdo et al., 2016). A potential explanation for our discordant findings is that the rat, not the mouse, has been the typical rodent species used to probe 5-HT's role in reversal learning. In addition, because perturbation of different 5-HT receptor subtypes, which presumably influence distinct circuitry, produces opposing effects on reversal learning (Furr et al., 2012; Nilsson et al., 2012), perhaps a near-complete absence of forebrain 5-HT has a net counterbalancing effect on reversal learning. A similar explanation may account for the lack of effect of adult brain Tph2 targeting on olfaction. With respect to reversal learning outcomes, however, this explanation does not account for the discrepancy between our findings and earlier ones in which 5-HT was also broadly depleted from the forebrain and therefore would have been expected to impact 5-HT signaling through more than one 5-HT receptor subtype. A conspicuous difference between our study and earlier ones, however, is the method used to deplete brain 5-HT. In contrast to our viral/genetic approach, previous studies have used pharmacological or dietary means to reduce brain 5-HT (Clarke et al., 2004, 2005,2007; Masaki et al., 2006; Lapiz-Bluhm et al., 2009; Bari et al., 2010; Izquierdo et al., 2012, 2016). Although off-target pharmacological effects are not potentially inherent in our Tph2 targeting approach, we cannot rule out the possibility that the severe deficiency of brain $5-\mathrm{HT}$ in Tph2 conditional knockout mice lasting several weeks before behavioral testing may have triggered presently unknown secondary effects, such as homeostatic alterations in the function of other transmitter systems, that compensate for the absence of 5-HT modulation of olfactory synaptic circuitry. Further parallel investigations of cognitive flexibility with adult Tph2-targeted mice and traditional methods of $5-\mathrm{HT}$ depletion are needed to resolve the mechanistic basis of previously reported effects, which, our results suggest, are not directly due to altered 5-HT levels.

Our findings prompt the question as to what role 5-HT does play in olfaction. Why do the essential olfactory structures receive massive 5-HT innervation if not for even adjusting the most essential functioning of the system? One possibility is that $5-\mathrm{HT}$ is needed only for the more nuanced aspects of odor-guided behavior, including the discrimination of structurally similar odorants (Cleland et al., 2002; Uchida and Mainen, 2003; Abraham et al., 2004), figure-background segregation (Barnes et al., 2008; Chapuis and Wilson, 2011), or intensity perception (Wojcik and Sirotin, 2014). For instance, a mouse may need 5-HT to discern the difference of odor in a sexually receptive female mouse versus an unreceptive one, yet may not need 5-HT to recognize the scent difference between a mouse and a predator. It is also possible that the influence of 5-HT would manifest only in cases of changes in behavioral state, including startle, arousal, or hunger. Nevertheless, our results, that the essential functions of the mammalian olfactory system can persevere despite a near-complete absence of adult brain 5-HT, are striking and suggest need for a refinement of models wherein $5-\mathrm{HT}$ serves a major role in the olfactory system.
Instead, we may benefit from recognizing a far more limited role of 5-HT in olfactory system function and perception. Further, this work provides a foundation to probe for compensatory synaptic mechanisms whereby our olfactory system may engage in informing behaviors, including those involving transmitter corelease (Trudeau, 2004; Zhou et al., 2005; Barker et al., 2016).

\section{References}

Abraham NM, Spors H, Carleton A, Margrie TW, Kuner T, Schaefer AT (2004) Maintaining accuracy at the expense of speed: stimulus similarity defines odor discrimination time in mice. Neuron 44:865876. CrossRef

Aungst JL, Shipley MT (2005) Serotonin modulation of external tufted cells in mouse olfactory bulb glomeruli. Chem Senses 30:A146.

Bari A, Robbins TW (2013) Inhibition and impulsivity: behavioral and neural basis of response control. Prog Neurobiol 108:44-79.

Bari A, Theobald DE, Caprioli D, Mar AC, Aidoo-Micah A, Dalley JW, Robbins TW (2010) Serotonin modulates sensitivity to reward and negative feedback in a probabilistic reversal learning task in rats. Neuropsychopharmacology 35:1290-1301. CrossRef

Barker DJ, Root DH, Zhang S, Morales M (2016) Multiplexed neurochemical signaling by neurons of the ventral tegmental area. $J$ Chem Neuroanat 73:33-42. CrossRef

Barnes DC, Hofacer RD, Zaman AR, Rennaker RL, Wilson DA (2008) Olfactory perceptual stability and discrimination. Nat Neurosci 11:1378-1380. CrossRef Medline

Bodyak N, Slotnick B (1999) Performance of mice in an automated olfactometer: odor detection, discrimination and odor memory. Chem Senses 24:637-645. Medline

Bouret S, Sara SJ (2005) Network reset: a simplified overarching theory of locus coeruleus noradrenaline function. Trends Neurosci 28:574-582. CrossRef

Bowker RM, Westlund KN, Coulter JD (1981) Origins of serotonergic projections to the spinal cord in rat: an immunocytochemicalretrograde transport study. Brain Res 226:187-199. CrossRef

Brill J, Shao Z, Puche AC, Wachowiak M, Shipley MT (2016) Serotonin increases synaptic activity in olfactory bulb glomeruli. J Neurophysiol 115:1208-1219. CrossRef Medline

Brunert D, Tsuno Y, Rothermel M, Shipley MT, Wachowiak M (2016) Cell-type-specific modulation of sensory responses in olfactory bulb circuits by serotonergic projections from the raphe nuclei. $J$ Neurosci 36:6820-6835. CrossRef

Cases O, Vitalis T, Seif I, De Maeyer E, Sotelo C, Gaspar P (1996) Lack of barrels in the somatosensory cortex of monoamine oxidase a-deficient mice: role of a serotonin excess during the critical period. Neuron 16:297-307. CrossRef

Chapuis J, Wilson DA (2011) Bidirectional plasticity of cortical pattern recognition and behavioral sensory acuity. Nat Neurosci 15: 155-161. CrossRef Medline

Chaudhury D, Escanilla O, Linster C (2009) Bulbar acetylcholine enhances neural and perceptual odor discrimination. J Neurosci 29:52-60. CrossRef Medline

Clarke HF, Dalley JW, Crofts HS, Robbins TW, Roberts AC (2004) Cognitive inflexibility after prefrontal serotonin depletion. Science 304:878. CrossRef

Clarke HF, Walker SC, Crofts HS, Dalley JW, Robbins TW, Roberts AC (2005) Prefrontal serotonin depletion affects reversal learning but not attentional set shifting. J Neurosci 25:532-538. CrossRef Medline

Clarke HF, Walker SC, Dalley JW, Robbins TW, Roberts AC (2007) Cognitive inflexibility after prefrontal serotonin depletion is behaviorally and neurochemically specific. Cereb Cortex 17:18. CrossRef Medline

Cleland TA, Morse A, Yue EL, Linster C (2002) Behavioral models of odor similarity. Behav Neurosci 116:222-231. 
Coccaro EF, Sripada CS, Yanowitch RN, Phan KL (2011) Corticolimbic function in impulsive aggressive behavior. Biol Psychiatry 69: 1153-1159. CrossRef Medline

Fletcher ML, Wilson DA (2002) Experience modifies olfactory acuity: acetylcholine-dependent learning decreases behavioral generalization between similar odorants. J Neurosci 22:RC201.

Furr A, Lapiz-Bluhm MD, Morilak DA (2012) 5-HT2A receptors in the orbitofrontal cortex facilitate reversal learning and contribute to the beneficial cognitive effects of chronic citalopram treatment in rats. Int J Neuropsychopharmacol 15:1295-1305. CrossRef

Gaspar P, Cases O, Maroteaux L (2003) The developmental role of serotonin: news from mouse molecular genetics. Nat Rev Neurosci 4:1002-1012. CrossRef Medline

Hardy A, Palouzier-Paulignan B, Duchamp A, Royet JP, DuchampViret P (2005) 5-Hydroxytryptamine action in the rat olfactory bulb: in vitro electrophysiological patch-clamp recordings of juxtaglomerular and mitral cells. Neuroscience 131:717-731. CrossRef

Hen R (1992) Of mice and flies: commonalities among 5-HT receptors. Trends Pharmacol Sci 13:160-165. Medline

Hurley LM, Devilbiss DM, Waterhouse BD (2004) A matter of focus: monoaminergic modulation of stimulus coding in mammalian sensory networks. Curr Opin Neurobiol 14:488-495. CrossRef

Izquierdo A, Brigman JL, Radke AK, Rudebeck PH, Holmes A (2016) The neural basis of reversal learning: an updated perspective. Neuroscience. Advance online publication. doi:10.1016/j.neuroscience.2016.03.021.

Izquierdo A, Carlos K, Ostrander S, Rodriguez D, McCall-Craddolph A, Yagnik G, Zhou F (2012) Impaired reward learning and intact motivation after serotonin depletion in rats. Behav Brain Res 233: 494-499. CrossRef

Jacobs BL, Azmitia EC (1992) Structure and function of the brain serotonin system. Physiol Rev 72:165-229. Medline

Johnson BA, Ho SL, Xu Z, Yihan JS, Yip S, Hingco EE, Leon M (2002) Functional mapping of the rat olfactory bulb using diverse odorants reveals modular responses to functional groups and hydrocarbon structural features. J Comp Neur 449:180-194. CrossRef

Kapoor V, Provost AC, Agarwal P, Murthy VN (2016) Activation of raphe nuclei triggers rapid and distinct effects on parallel olfactory bulb output channels. Nat Neurosci 19:271-282. CrossRef Medline

Katz PS (1999) Beyond neurotransmission: neuromodulation and its importance for information processing. Oxford University Press: Oxford, UK.

Kelliher KR, Ziesmann J, Munger SD, Reed RR, Zufall F (2003) Importance of the CNGA4 channel gene for odor discrimination and adaptation in behaving mice. Proc Natl Acad Sci U S A 100:4299-4304. CrossRef Medline

Kim J-Y, Kim A, Zhao Z-Q, Liu X-Y, Chen Z-F (2014) Postnatal maintenance of the $5-\mathrm{Ht} 1 \mathrm{a}-\mathrm{Pet} 1$ autoregulatory loop by serotonin in the raphe nuclei of the brainstem. Mol Brain 7:1-11. CrossRef Medline

Lapiz-Bluhm MDS, Soto-Piña AE, Hensler JG, Morilak DA (2009) Chronic intermittent cold stress and serotonin depletion induce deficits of reversal learning in an attentional set-shifting test in rats. Psychopharmacology (Berl) 202:329-341. CrossRef

Lerch-Haner JK, Frierson D, Crawford LK, Beck SG, Deneris ES (2008) Serotonergic transcriptional programming determines maternal behavior and offspring survival. Nat Neurosci 11:1001-1003. CrossRef

Lin W, Arellano J, Slotnick B, Restrepo D (2004) Odors detected by mice deficient in cyclic nucleotide-gated channel subunit A2 stimulate the main olfactory system. J Neurosci $24: 3703-3710$. CrossRef

Linster C, Cleland TA (2002) Cholinergic modulation of sensory representations in the olfactory bulb. Neural Netw 15:709-717. CrossRef

Linster C, Cleland TA (2016) Neuromodulation of olfactory transformations. Curr Opin Neurobiol 40:170-177. CrossRef
Linster C, Fontanini A (2014) Functional neuromodulation of chemosensation in vertebrates. Curr Opin Neurobiol 29:82-87. CrossRef Medline

Liu S, Aungst JL, Puche AC, Shipley MT (2011a) Serotonin modulates the population activity profile of olfactory bulb external tufted cells. J Neurophysiol 107:473-483. CrossRef Medline

Liu Y, Jiang Y, Si Y, Kim J-Y, Chen Z-F, Rao Y (2011b) Molecular regulation of sexual preference revealed by genetic studies of $5-\mathrm{HT}$ in the brains of male mice. Nature 472:95-99. CrossRef

Liu Z, Zhou J, Li Y, Hu F, Lu Y, Ma M, Feng Q, Zhang J, Wang D, Zeng J, Bao J, Kim J-Y, Chen Z-F, El Mestikawy S, Luo M (2014) Dorsal raphe neurons signal reward through 5-HT and glutamate. Neuron 81:1360-1374. CrossRef

Lottem E, Lörincz ML, Mainen ZF (2016) Optogenetic activation of dorsal raphe serotonin neurons rapidly inhibits spontaneous but not odor-evoked activity in olfactory cortex. J Neurosci 36:7-18. CrossRef

Macrides F, Eichenbaum HB, Forbes WB (1982) Temporal relationship between sniffing and the limbic theta rhythm during odor discrimination reversal learning. J Neurosci 2:1705-1711. Medline

Mandairon N, Ferretti CJ, Stack CM, Rubin DB, Cleland TA, Linster C (2006) Cholinergic modulation in the olfactory bulb influences spontaneous olfactory discrimination in adult rats. Eur J Neurosci 24:3234-3244 CrossRef

Masaki D, Yokoyama C, Kinoshita S, Tsuchida H, Nakatomi $Y$, Yoshimoto K, Fukui K (2006) Relationship between limbic and cortical 5-HT neurotransmission and acquisition and reversal learning in a go/no-go task in rats. Psychopharmacology (Berl) 189:249-258. CrossRef

McLean JH, Darby-King A, Sullivan RM, King SR (1993) Serotonergic influence on olfactory learning in the neonate rat. Behav Neural Biol 60:152-162. CrossRef

McLean JH, Shipley MT (1987) Serotonergic afferents to the rat olfactory bulb: I. Origins and laminar specificity of serotonergic inputs in the adult rat. J Neurosci 7:3016-3028. Medline

Moriizumi T, Tsukatani T, Sakashita H, Miwa T (1994) Olfactory disturbance induced by deafferentation of serotonergic fibers in the olfactory bulb. Neuroscience 61 733-738. Medline

Murphy F, Smith K, Cowen P, Robbins T, Sahakian B (2002) The effects of tryptophan depletion on cognitive and affective processing in healthy volunteers. Psychopharmacology (Berl) 163:42-53. CrossRef

Muzerelle A, Scotto-Lomassese S, Bernard JF, Soiza-Reilly M, Gaspar $P(2016)$ Conditional anterograde tracing reveals distinct targeting of individual serotonin cell groups (B5-B9) to the forebrain and brainstem. Brain Struct Funct 221:535-561. CrossRef

Nilsson SRO, Ripley TL, Somerville EM, Clifton PG (2012) Reduced activity at the $5-\mathrm{HT} 2 \mathrm{C}$ receptor enhances reversal learning by decreasing the influence of previously non-rewarded associations. Psychopharmacology (Berl) 224:241-254. CrossRef

Paxinos G, Franklin K (2000) The mouse brain in stereotaxic coordinates, 2nd ed. San Diego: Academic Press.

Petzold GC, Hagiwara A, Murthy VN (2009) Serotonergic modulation of odor input to the mammalian olfactory bulb. Nat Neurosci 12:784-791. CrossRef Medline

Pfaffmann C, Goff WR, Bare JK (1958) An olfactometer for the rat. Science 128:1007-1008. Medline

Pho V, Butman ML, Cherry JA (2005) Type 4 phosphodiesterase inhibition impairs detection of low odor concentrations in mice. Behav Brain Res 161:245-253. CrossRef Medline

Ravel N, Vigouroux M, Elaagouby A, Gervais R (1992) Scopolamine impairs delayed matching in an olfactory task in rats. Psychopharmacol 109:439-443. Medline

Saar D, Grossman Y, Barkai E (2001) Long-lasting cholinergic modulation underlies rule learning in rats. J Neurosci 21:1385-1392. Medline

Schmidt LJ, Strowbridge BW (2014) Modulation of olfactory bulb network activity by serotonin: synchronous inhibition of mitral cells mediated by spatially localized GABAergic microcircuits. Learn Mem 21:406-416. CrossRef 
Schoenbaum G, Chiba AA, Gallagher M (1999) Neural encoding in orbitofrontal cortex and basolateral amygdala during olfactory discrimination learning. J Neurosci 19:1876-1884.

Siopi E, Denizet M, Gabellec M-M, de Chaumont F, Olivo-Marin J-C, Guilloux J-P, Lledo P-M, Lazarini F (2016) Anxiety- and depression-like states lead to pronounced olfactory deficits and impaired adult neurogenesis in mice. $J$ Neurosci 36:518-531. CrossRef

Skagerberg G, Björklund A (1985) Topographic principles in the spinal projections of serotonergic and non-serotonergic brainstem neurons in the rat. Neuroscience 15:445-480. Medline

Slotnick B, Restrepo D (2001) Olfactometry with mice. In: Current protocols in neuroscience. Wiley: New York.

Smith RL, Baker H, Greer CA (1993) Immunohistochemical analyses of the human olfactory bulb. J Comp Neur 333:519-530.

Sokolic L, McGregor IS (2007) Benzodiazepines impair the acquisition and reversal of olfactory go/no-go discriminations in rats. Behav Neurosci 121:527-534. CrossRef Medline

Steinfeld R, Herb JT, Sprengel R, Schaefer AT, Fukunaga I (2015) Divergent innervation of the olfactory bulb by distinct raphe nuclei. J Comp Neur 523:805-813. CrossRef Medline

Suzuki Y, Kiyokage E, Sohn J, Hioki H, Toida K (2015) Structural basis for serotonergic regulation of neural circuits in the mouse olfactory bulb. J Comp Neur 523:262-280. CrossRef Medline
Toda T, Homma D, Tokuoka H, Hayakawa I, Sugimoto Y, Ichinose H, Kawasaki H (2013) Birth regulates the initiation of sensory map formation through serotonin signaling. Dev Cell 27:32-46. CrossRef

Trudeau LE (2004) Glutamate co-transmission as an emerging concept in monoamine neuron function. J Psychiatry Neurosci 29: 296-310. Medline

Uchida N, Mainen ZF (2003) Speed and accuracy of olfactory discrimination in the rat. Nat Neurosci 6:1224-1229.

Walther DJ, Peter JU, Bashammakh S, Hörtnagl H, Voits M, Fink H, Bader M (2003) Synthesis of serotonin by a second tryptophan hydroxylase isoform. Science 299:76. CrossRef

Wesson DW, Keller M, Douhard Q, Baum MJ, Bakker J (2006) Enhanced urinary odor discrimination in female aromatase knockout (ArKO) mice. Horm Behav 49:580-586. CrossRef Medline

Whitney MS, Shemery A, Yaw A, Donovan L, Glass JD, Deneris ES (2016) Adult brain serotonin deficiency causes hyperactivity, circadian disruption, and elimination of siestas. J Neurosci 36:98289842. CrossRef Medline

Wojcik PT, Sirotin YB (2014) Single scale for odor intensity in rat olfaction. Curr Biol 24:568-573. CrossRef Medline

Zhou F-M, Liang Y, Salas R, Zhang L, De Biasi M, Dani JA (2005) Corelease of dopamine and serotonin from striatal dopamine terminals. Neuron 46:65-74. CrossRef 